\section{ОРГАНІЗАЦІЯ ВИРОБНИЧО- ПРОМИСЛОВОЇ ДІЯЛЬНОСТІ КОНЦЕРНУ «УКРХУДОЖПРОМ»}

\author{
Варивончик Анастасія Віталіївна \\ Кандидат мистеитвознавства, доцент, \\ ORCID: 0000-0002-4455-1109, \\ e-mail:varivonchik@ukr.net, \\ Київський університет ім. Бориса Грінченка, \\ вул. Бульварно-Кудрявська, 18/2, Київ, Украӥна, 04053
}

\begin{abstract}
Метою дослідження є висвітлення організаційних процесів (або організаційної складової виробничо-промислової діяльності) технічно-експериментальних лабораторій концерну «Укрхудожпром»; виявлення специфіки створення та виконання експериментальних виробів із застосуванням унікальних українських художніх промислів, таких як вишивка на Виробничо-художньому об'єднанні імені Т. Г. Шевченка. Методологія дослідження грунтується на використанні як загальнонаукових методів (аналіз, синтез, узагальнення, індукція, дедукція), так і суто мистецтвознавчих історико-культурного, реконструктивно-модельного, хронологічної дескрипції, що сприяють розкриттю еволюції та розвитку творчо-виробничої діяльності лабораторій концерну «Укрхудожпром». Наукова новизна полягає у виявленні виробничо-промислової специфіки діяльності підприємств концерну «Укрхудожпром», виробів з використанням вишивки, що у подальшому розвинулося в масовому виробництві одягу і предметів повсякденного вжитку. Висновки. У статті узагальнені особливості діяльності технічно-експериментальної лабораторії виробництва, в якій працювали досвідчені художники-професіонали під керівництвом головного художника. Вироби експериментальної лабораторії один раз на три місяці переглядались та затверджувались на художній раді в Центральній художній експериментальній лабораторії «Укрхудожпром», прописувалась кількість асортименту, яка може бути виготовлена за кожним зразком. Маючи дозвіл на подальше впровадження, виробництво виконувало вироби малих партій або масового виробництва. Затверджені експериментальні вироби під назвою зразок-еталон завжди зберігалися в експериментальній лабораторії підприємства для звірки. Після завершення виконання виробів масового виробництва, зразком-еталоном завжди керувався відділ технічного контролю ВТК. Виробничо-художнє об'єднання ім. Т. Г. Шевченка запроваджувало і складало новий асортимент і моделі художньої промисловості на території України.
\end{abstract}

Ключові слова: виробництво, художня промисловість, технічно-експериментальна лабораторія, вишивальниці.

\title{
Ветуп
}

Мистецтво як художня творчість - один із різновидів виробництва, специфіка якого у розробленні ідей про предмети. Спочатку індивідуальна праця стає промислом і стимулює удосконалення форм суспільної (колективної) організації праці. На зміну індивідуальному виробництву «приходить» кооперація (співробітництво), далі - мануфактура, фабрика, індустрія.

Аналіз історичного розвитку художніх промислів в Україні неспростовно підтверджує цю закономірність. Українські художні промисли поетапно видозмінюються - від виготовлення одягу та його прикрашання (вишивка), виготовлення декоративних прикрас (петриківський розпис) - до різьбярства і килимарства (Антонович, Захарчук-Чугай та Станкевич, 1992, с. 131-132).

Значна роль у художньо-промисловому розвитку України належить об’єднанню «Укрхудожпром», яке бере початок від діяльності Української художньо-промислової спілки у 30-х роках XX ст. у складі 119 артілей. Згодом, у результаті численних реорганізацій мережа Главхудожпрому до 1973 р. налічувала 24 фабрики, завод, чотири промислово-художні об'єднання, Київську базу, фірмовий універмаг і Центральну художньо-експериментальну лабораторію. 31988 р. до складу вкотре реорганізованого виробничоторговельного об'єднання увійшли такі підприємства як: фабрика «Вінничанка» (м. Вінниця); фабрика імені Т. Г. Шевченка (м. Київ); фабрика «Гуцульщина» (м. Косів); фабрика «Полтавчанка» (м. Полтава); фабрика «Україна» (м. Харків); фабрика «Петриківська розпис» (смт. Петриківка); фабрика «Донбас» (м. Донецьк); фабрика імені Р. Люксембург (м. Івано-Франківськ); фабрика ім. 17 Вересня (м. Коломия); фабрика «Богуславка» (м. Богуслав); фабрика імені Б. Хмельницького (м. Переяслав-Хмельницький); фабрика ім. Лесі Українки (м. Львів) та десяток інших (Киселева, 1980, с. 5-7).

(C) Варивончик А. В., 2019 
31994 р. на базі підприємств та організацій Українського концерну художніх промислів «Укрхудожпром» створене Державне акціонерне товариство «Укрхудожпром», яке вже у 2004 р. ліквідовано у зв'язку із банкрутством.

\section{Мета статті}

Метою дослідження $є$ висвітлення організаційних процесів (або організаційної складової виробничо-промислової діяльності) технічно-експериментальних лабораторій концерну «Укрхудожпром»; виявлення специфіки створення та виконання експериментальних виробів із застосуванням унікальних українських художніх промислів, таких як вишивка на Виробничохудожньому об’єднанні імені Т. Г. Шевченка.

\section{Виклад матеріалу дослідження}

Головним підприємством «Укрхудожпрому» було Виробничо-художнє об’єднання ім. Т. Шевченка, до нього належали дванадцять філіалів у Київський області: Біла Церква, Васильків, Гоголів, Горенка, Гнідин, Гостомель, Оленівка, Іванків, Кагарлик, Літки, Миронівка, Чорнобиль (Кара-Васильєва, 1993, c. 140).

У 1930 р. на Київщині функціонували двадцять вишивальних осередків. Починаючи з 1930-1931 рр., художньо-вишивальна промисловість Київщини підпорядкувалась київському товариству «Текстильекспорт», які повністю працювали на продаж для закордонних держав. У цих місцевостях артілі посідали перші місця та були найуспішнішими у вишивальному українському промислі. У 1934 р. всі артілі були об’єднанні у Київське виробничо-художнє об’єднання ім. Т. Г. Шевченка, яке увійшло в «Укрхудожпром», а в 1974 р. фабрика отримала назву Виробничохудожне об’єднання ім. Т. Г. Шевченка (Кара-Васильєва, 1993, с. 140).

Готова продукція з філій привозилась на склад виробництва, проходила відділ технічного контролю та розвозились до торговельних мереж.

На виробництві раз на місяць проходили художні ради, рада складалась із представників основних відділів і провідних представників виробництва: художників, модельєрів, конструкторів із одягу. На художній раді затверджувались і пропонувались на розгляд у художню раду «Укрхудожпрому», яка розташовувалась на вулиці Воровського 22, де погоджували зразки відповідно до вимог художніх промислів, із дотриманням національних традицій в одязі та речах побуту і пропонували для запуску в масове виробництво.

Згідно з критеріями щодо оцінки художніх і технічних якостей виробів складався протокол виробів затвердженим для масового виробництва і прямував до промислових підприємств з рекомендаціями до випуску в масове виробництво.

Для художників і конструкторів виробництва кожний місяць виписувались журнали мод вітчизняного та закордонного видання, такі як Бурда та інші. Кожні півроку художники і конструктори виробництва запрошувались Центральним будинком моделей (вул. Шота Руставелі, 16) на покази мод, тим самим знайомились із новими тенденціями моди на наступний сезон.

Виробничо-художні об’єднання концерну «Укрхудожпром» мали технічно-експериментальні лабораторії, в яких працювали дипломовані фахівці: головний художник, начальник експериментальної лабораторії, конструктори, художники, технологи, майстри 3 виконання виробів (Киселева, Кара-Васильєва та Придатко, 1979, с. 212).

Експериментальна лабораторія підпорядковувалась головному художнику i начальнику експериментальної лабораторії. Для створення нової моделі на виробництві головний художник і начальник надавали конструктору і художнику з вишивки час на розробку лекал і виготовлення зразка затвердженого виробу, а також розробку конфекційної карти. У кожного художника і конструктора був місячний план зі створення моделі й вишивки до кожного виробу. За планом художник за місяць повинен був створити 6 малюнків будь-яких речей. Це могли бути скатертини, серветки, одяг, які створювалися спільно із конструктором.

У конфекційній карті подавалась модель та прізвище вишивальниці, яка відшивала цю експериментальну модель; вишивальниця Л. Баранська Обов'язково на конфекційній карті залишався один край вишивки, де можна було переглянути зворотній бік. На відшивку цього малюнка використали 8 грамів ниток та 16 годин, також враховувалась ціна тканини, ниток та пошиття. За цими даними 
складалась зарплатня вишивальниць, які вишивали сорочку для масового виробництва. Після пошиття виробу формувалась загальна ціна на вишивку, пошив, прасування, пакування і визначалася ціна для продажу у роздрібній торгівлі (рис.1., 2.).

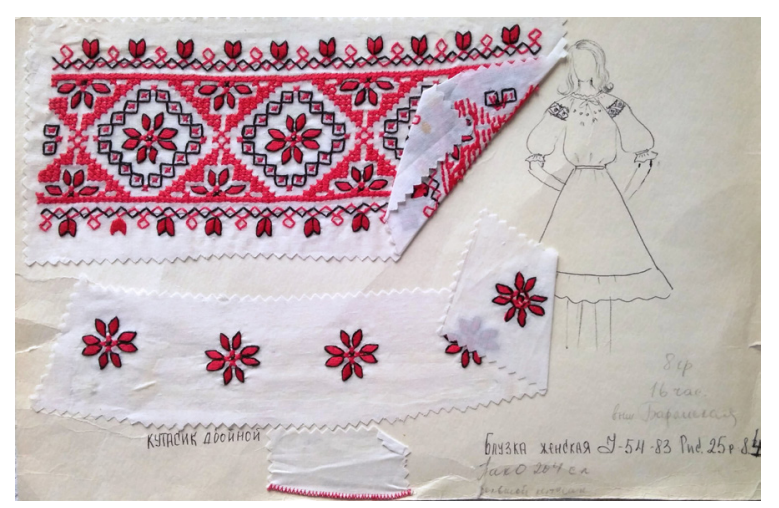

Рис. 1. Конфекційна картка на модель жіночої блузки У-54-83 (1984 p.)

Fig 1. Confectionery card for the model of women's blouse У-54-83 (1984)

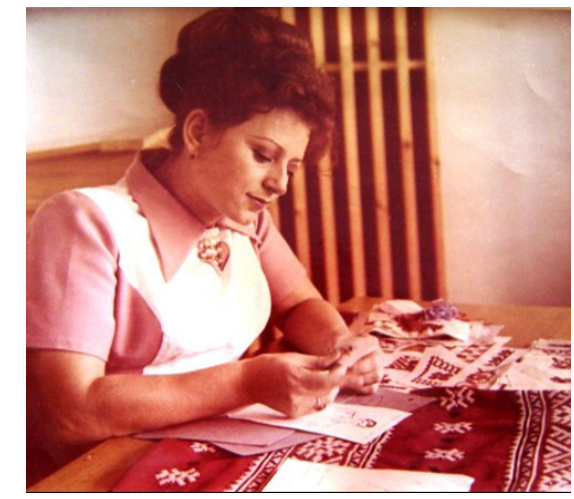

Рис. 2. Художник експериментальної лабораторії Срмаченкова В. працює над створенням малюнка нового жіночого виробу (1973 р.)

Fig. 2. The artist of the experimental laboratory Yermachenkova V. works on the creation of a picture of a new female product (1973)

Модель рис.1 була розроблена за № У-54 в 1983 р., після затвердження блузка отримала №25 і вже випускалась в масовому виробництві у 1984 p.

Співробітники експериментальної лабораторії шили зразок-еталон та навішували ярлик, який завіряв представник відділу технічного контролю. Зразок-еталон зберігали в експериментальній лабораторії для звірки із цим виробом. Згідно з графіком запуску нових виробів у масове виробництво, технологом розроблялась технічна і технологічна документація на пошив і вишивку виробу і спільно з лаборантом експериментального цеху у цехи філіалів об'єднання у Київській області виїжджав технолог. Лаборант навчала робітників філій виготовленню нових виробів, крій яких заготовляли у розкрійному цеху об'єднання та привозили до філій. Після пошиття вироби перевозились до Києва, перевірялись робітниками відділу технічного контролю і звірялись зі зразком-еталоном, який перебував в експериментальній лабораторії. Вироби, що пройшли перевірку, проходили волого-теплову обробку, упаковувались у промислову тару і відправлялись на склад. У майбутньому їх передавали на торгову базу, з якою були укладені торговельні договори.

Виробництво відвідували школярі навчально-промислового комбінату на базі школи № 3 Шевченківського району міста Києва. Шефськими зусиллями фабрики ім. Т. Шевченка було встановлено та налагоджено швацький цех у 1984 р., де школярі старших класів у вільний від навчання час навчались швацькій справі та шили для об'єднання сувенірні серветки, які заздалегідь вишивали школярі УВК (учбововиробничого комплексу) Сирецького району за адресою: вул. Щусєва, 20. Тим самим ознайомлювали школярів із виробничими професіями та готували молодь до отримання робітничих спеціальностей.

Наприкінці 80-х років ХХ ст. на виробництві відбулись зміни: 10.01 .1989 року у зв'язку із введенням нових умов оплати праці Постановою ЦК КПРС РМ СРСР і ВЦРПС встановлено, що виробничо-художнє об'єднання ім. Т. Г. Шевченка перейменовано у фабрику ім. Т. Г. Шевченка (Антонович, Захарчук-Чугай та Станкевич, 1992, с. 140).

З 1992 р. художні ради проходили тільки на виробництві в експериментальній лабораторії, а одяг який були виконано в експериментальній лабораторії, пройшовши затвердження, випускались лише за рішенням ради виробництва. 3 того ж часу виробництво перейшло на самоокупність і самофінансування, і працювало лише на замовлення. Підприємство виробляло речі з вишивкою для самодіяльних колективів, дизайнерів на українські покази «Сезони моди», а також виконувало власні замовлення.

Вироби Київського виробничо-художнього об’єднання ім. Т. Шевченка експонувались на міжнародних і республіканських виставках, виробництво нагороджувалось дипломами і медалями, вироби експортувалась до різних країн. А на підприємстві у той час вже працювало понад 1500 тис. осіб і більшість робітників було у філіях в Києві, у центральному корпусі працювали 400 осіб (Варивончик, 2012 , c. 240$)$. 
У 1995 р. виробничо-художнього об'єднання ім. Т. Шевченка було перейменоване на Закрите акціонерне товариство «Виробничо-художнє об'єднання ім. Т. Г. Шевченка».

У 2000-х рр. ЗАТ ВХО ім. Т. Г. Шевченка працювало під замовлення, які робили готелям «Україна», «Національний», постачаючи вишиту постільну білизну, серветки, скатертини. Шили костюми для хорів, дитячого ансамблю «Співаночка», зокрема й хору ім. Г. Г. Верьовки, ансамблю ім. П. П. Вірського. Для міжнародного благодійного фонду Святої Марії виконували замовлення - вишивали пасхальні серветки, скатертини. Магазин «Дім подарунків» замовляв вишиту постільну білизну, обрядові рушники. Також вишивали логотипи фірм і закладів.

У 2004 р. виробництво було закрите, багато висококваліфікованих фахівців - художників, конструкторів, майстрів, робітниць-вишивальниць втратили роботу, а разом 3 цим утворилась лакуна, розрив у національній традиції. У країні ніби заново з'являються невеличкі власні підприємства, схожі на артілі, які існували на початку XX ст., де на невисокому художньому рівні виготовлялись художні вишивальні вироби, а нинішні майстри не мають вже належної кваліфікації. На жаль, сьогодні втрачена і мережа торгових підприємств, де можна вільно придбати речі народної творчості. Відтак майбутні художні промисли України перебувають під загрозою знищення.

\section{Висновки}

У статті досліджено особливості виробництва художніх промислів України на прикладі підприємств концерну «Укрхудожпром». На виробництвах «Укрхудожпрому» застосовувалися критерії і методологічні рекомендації з оцінки художнього рівня і технічної якості виробів народних художніх промислів, що випускали виробництва місцевої промисловості та інші відомства. Вироби експериментальної лабораторії періодично переглядались та затверджувались Центральною художньою експериментальною лабораторією «Укрхудожпрому». Експериментальні вироби завжди зберігалися в експериментальній лабораторії підприємства для звірки, а Виробничо-художнє об'єднання ім. Т. Г. Шевченка запроваджувало і складало новий асортимент і моделі художньої промисловості на території України. На жаль, унаслідок економічного занепаду почалось закриття переважної більшості виробництв художньої промисловості, така доля випала і Київському виробничо-художньому об’єднанню імені Т. Г. Шевченка. Виробництво «Укрхудожпром» не витримало ринкової конкуренції. Порушились економічні зв'язки, з'явились значні проблеми з постачанням сировини, технічно застаріло обладнання на підприємствах, зійшла нанівець підтримка держави цього сектору економіки та культури, що і спричинило поступову ліквідацію виробничо-художніх об'єднань.

На основі поданого матеріалу автор вбачає перспективи подальших досліджень у напрямку виробничопромислової специфіки та діяльності підприємств виробничо-художніх об'єднань в яких виготовляли вироби з використанням української вишивки.

\section{Список використаних джерел}

1. Антонович Є. Захарчук-Чугай Р., Станкевич М. Декоративно-прикладне мистещтво. Львів : Світ, 1992. $270 \mathrm{c}$.

2. Варивончик А. В. Унікальний досвід майстринь-вишивальниць Київщини. Вісник КНУКіМ. Серія: Мистецттвознавство. Київ, 2012. Вип. 13. С. 237-245.

3. Кара-Васильєва Т. В. Українська вишивка. Київ : Мистецтво, 1993. 263 с.

4. Киселева Н., Кара-Васильєва Т., Придатко Т. Художні промисли Украӥни. Київ : Мистецтво, 1979. 253 с.

5. Киселева Н. М. Художні промисли Украӥни. Київина. Київ : Мистецтво, 1980. 18 с.

6. Павлюк С. П. Скарби Музею етнографії та художнього промислу Інституту народознавства НАН України. Львів: [б.в.], 2005. 228 с.

\section{References}

Antonovych, Ye., Zakharchuk-Chuhai, R. and Stankevych, M. (1992). Dekoratyvno-prykladne mystetstvo [DecorativeApplied Arts]. Lviv: Svit.

Kara-Vasylieva, T. (1993). Ukrainska vyshyvka [Ukrainian embroidery]. Kyiv: Mystetstvo.

Kyseleva, N., Kara-Vasylieva, T. and Prydatko, T. (1979). Khudozhni promysly Ukrainy [Art crafts of Ukraine]. Kyiv: Mystetstvo. 
Kyseleva, N. (1980). Khudozhni promysly Ukrainy. Kyivshchyna [Art crafts of Ukraine. Kyiv region]. Kyiv: Mystetstvo. Pavliuk, S. (2005). Treasures of the Museum of Ethnography and Crafts of the Institute of Ethnology of the National Academy of Sciences of Ukraine [Skarby Muzeiu etnohrafii ta khudozhnioho promyslu Instytutu narodoznavstva NAN Ukrainy]. Lviv.

Varyvonchyk, A. (2012). Unique experience of masters-embroideresses of Kiev region [Unikalnyi dosvid maistrynvyshyvalnyts Kyivshchyny], Visnyk KNUKiM. Seriia: Mystetstvoznavstvo, issue 13, pp. 237-245.

Стаття надійшла до редакиії: 13.03.2019

\begin{abstract}
ОРГАНИЗАЦИЯ ПРОИЗВОДСТВЕННОПРОМЫШЛЕННОЙ ДЕЯТЕЛЬНОСТИ КОНЦЕРНА «УКРХУДОЖПРОМ»

Варивончик Анастасия Витальевна

Кандидат искусствоведения, доцент,

Киевский университет имени Бориса Гринченко,

Киев, Украина
\end{abstract}

Целью исследования является освещение организационных процессов (или организационной составляющей производственно-промышленной деятельности) технико-экспериментальных лабораторий концерна «Укрхудожпром»; выявление специфики создания и выполнения экспериментальных изделий с применением уникальных украинских художественных промыслов, таких как вышивка на Производственно-художественном объединении имени Т. Г. Шевченко. Методология исследования основывается на использовании в качестве общенаучных методов (анализ, синтез, обобщение, индукция, дедукция), так и чисто искусствоведческих историко-культурного, реконструктивно-модельной, хронологической дескрипции, способствующие раскрытию эволюции и развития творчески-производственной деятельности лабораторий концерна «Укрхудожпром». Научная новизна заключается в выявлении производственно-промышленной специфики деятельности предприятий концерна «Укрхудожпром», изделий с использованием вышивки, в дальнейшем развилось в массовом производстве одежды и предметов повседневного обихода. Выводы. В статье обобщены особенности и деятельность технически экспериментальной лаборатории производства, в которой работали опытные художники профессионалы под руководством главного художника. Изделия экспериментальной лаборатории один раз в три месяца пересматривались и утверждались на художественном совете в Центральной художественной экспериментальной лаборатории «Укрхудожпром». Утвержденные экспериментальные изделия под названием образец-эталон, сохранялись в экспериментальной лаборатории предприятия для сверки отдела технического контроля ОТК. Производственно-художественное объединение им. Т. Г. Шевченко внедряло и составляло новые ассортименты и модели художественной промышленности на территории Украины.

Ключевые слова: производство; художественная промышленность; технически-экспериментальная лаборатория; вышивальщицы.

\title{
ORGANIZATION OF PRODUCTION $\mid$ Anastasiia Varyvonchyk AND INDUSTRIAL ACTIVITY AT THE $\quad$ PhD in Art History, Associate Professor, “UKRKHUDOZHPROM" CONCERN Borys Grinchenko Kyiv University, Kyiv, Ukraine
}

The purpose of the article is to cover the organizational processes (or the organizational component of production and industrial activity) implemented at technical and experimental laboratories of the "Ukrkhudozhprom" concern; to reveal the specifics of designing and manufacturing experimental products with the use of unique Ukrainian art crafts such as embroidery at the Taras Shevchenko Production and Art Association. The research methodology was based on the use of both general scientific methods (analysis, synthesis, generalization, induction, deduction) and purely artistic methods, such as historical-cultural, reconstructive-model, and chronological-descriptive, which helped to reveal the evolution and development of creative and production activity of the laboratories of the "Ukrkhudozphrom" concern. The scientific novelty of the work lies in the identification of the production and industrial specifics of the enterprises of the "Ukrkhudozhprom" concern, and the products using embroidery, which subsequently developed in the mass production of clothing and everyday objects. Conclusions. The article summarizes the characteristic features and activity of the technical and experimental production laboratory, in which experienced professional artists worked under the guidance of the art director. The products of the experimental laboratory were reviewed and approved once every three months at the 


\section{ДИЗАЙН}

ISSN 2410-1176 (Print) • Вісник КНУКіМ. Серія: Мистецтвознавство. Вип. 40 • ISSN 2616-4183 (Online)

Arts Council at the Central Art Experimental Laboratory of "Ukrkhudozhprom", with the number of items which could be made per sample specified. Having a sales permit, the production facility manufactured goods in small or large lots. The approved experimental products, which were called model samples, were always stored at the experimental laboratory of the enterprise for verification. After the completion of the large-lot production process, the model sample was always followed by the technical control unit. The Taras Shevchenko Production and Art Association introduced and designed new assortment and models of the art industry in Ukraine.

Keywords: production; art industry; technical and experimental laboratory; embroideresses. 